\title{
Post-Medium Literature? Two Examples of Contemporary Scandinavian "Literature"
}

\author{
Jørgen BRUHN \\ Linnæus University, Växjö \\ Department of Film and Literature \\ jorgen.bruhn@lnu.se
}

\begin{abstract}
This article discusses two contemporary Scandinavian literary texts: Ursula Andkjær Olsen's Danish book of poetry called Havet er en scene [The Sea Is a Stage], and Abo Rasul's (pseudonym for Matias Faldbakken) Norwegian novel Unfun. I intend to show that these texts exemplify two very different but nevertheless comparable positions in contemporary Scandinavian literature. Despite the differences, they resemble each other in that they actively mix medial constellations to offer social critique, and the aim of this article is thus to investigate the specific relation between medial mixture and social critique.
\end{abstract}

Keywords: Intermediality, post-medium, Rosalind Krauss, Abo Rasul/Matias Faldbakken, Ursula Andkjær Olsen

\section{Introduction}

The role of literature in Western societies has changed in recent decades. Intermediality scholar Werner Wolf is probably right when he states that television (which broadcasts reality shows, feature films and news) has been the "unchallenged leading medium" for some time. ${ }^{1}$ Wolf also notes that television is in the process of being overtaken by the form and content of the World Wide Web, as it becomes the new leading medium. Compared to the 1970s or 1980s, literature has lost its position as the self-evident, central cultural reference. Literature has not disappeared, but it is included in cultural circuits and ideological debates, mixed with other media in complicated overlaps and cooperative efforts. For example, literary form and content have moved from the book to "quality TV,"

1 For a discussion from an intermedial point of view of the idea of literature as a "Leitmedium," a leading medium in the paragone of the arts and media, see Wolf 2010. 
with TV series such as The Wire, The Sopranos or Mad Men seen as the obvious heirs to the large-scale realistic novel. As noted by a New York Times commentator, "if Charles Dickens were alive today, he would watch The Wire, unless, that is, he was already writing for it” (Kulish 2006).

The thesis that lies at the heart of this article is the fundamental "mixed" condition of all texts and all media. ${ }^{2}$ In another context I refer to this condition as "heteromediality" (Bruhn 2010), meaning that every text is mixed in different ways, due to the fact that the specific combination of media is determined according to ideological contexts and historical institutions as well as the aesthetic or existential aims of the individuals involved. However, there is no natural or pre-given correlation between the mixed character of texts and progressive aesthetic or ideological potentials: I do not claim that mixing media is aesthetically satisfying or socially progressive per se.

Ursula Andkjær Olsen's Danish book of poetry called Havet er en scene [The Sea Is a Stage] and Abo Rasul/Matias Faldbakken's Norwegian novel Unfun, both published in 2008, exemplify two different "literary" positions in contemporary Scandinavian culture. Nevertheless, they resemble each other in that they actively mix medial constellations to provide political critique, and the aim of the article is thus to investigate the specific relationship between medial mixture and social critique in these texts.

\section{Three perspectives on contemporary medial mixture: Spielmann, Schröter, Krauss}

In New and Novelty in Contemporary Media Cultures (2010), German media theorist Yvonne Spielmann describes the invasion of mixed media culture (primarily transmitted by digital technology) into our everyday lives. The mixing and remediating of conventional, distinct media forms characterise contemporary media and technology, but according to Spielmann, new intermedial products threaten to stress, stupefy and alienate individuals. Spielmann presents contemporary artists who create "pockets of resistance" around, beside, or beyond what she sees as the attempt of global communication networks to monopolise human existence. In contrast to the all-dominant commercial mixes, these artists create intermedial constellations that question and disturb the commercially produced intermediality of corporate capitalism. Indeed, Spielmann frames their intermedial activity as subversive interventions into today's media landscapes,

2 W. J. T. Mitchell has formulated influential catchphrases for this, first stating that "all media are mixed media" (Mitchell 1994, 4). A few years later, Mitchell modified his statement, saying that "[a]ll media are, from the standpoint of sensory modality, 'mixed media'” (Mitchell 2005). 
and consequently she describes these creative practices as "media behaviour against the grain" (Spielmann 2010, 13).

In a related, recent article, German media theorist and film scholar Jens Schröter develops and discusses the well-known dichotomy of medium specificity (represented by Greenberg) and the Gesamtkunstwerk tradition (represented by Higgins); the differences between these positions constitute what he considers to be the "politics of intermediality" in twentieth-century thought. According to Clement Greenberg, the mix of media should be avoided, and as late as 1981 he states: "What's ominous is that the decline of taste now, for the first time, threatens to overtake art itself. I see 'intermedia' and the permissiveness that goes with it as symptom of this. [...] Good art can come from anywhere, but it hasn't yet come from intermedia or anything like it” (Greenberg quoted in Schröter 2010, 110). For Greenberg, then, the mixing of media limits art's ability to go against the grain of commercialism and kitsch, and in Schröter's assessment, "this position views intermediality as a capitulation of art to capitalist spectacle culture" (Schröter 2010, 112). However, as both Schröter and Spielmann demonstrate, the mixing of the arts (Greenberg's "intermedia”) may also be interpreted as a liberating practice that opposes commercialism and alienation.

One might object that Higgins and Greenberg are not discussing the same phenomenon: art critic Greenberg is interested in (and even worried about) the future of the arts, whereas Higgins himself is an artist and editor who creates performance art and publishes work in the avant-garde tradition. Nevertheless, Schröter's examination clarifies that medial mixedness is both a central aspect of modern and postmodern art and critical thinking. Furthermore, and equally important, he demonstrates the ideological implications of the mixing of media.

Art critic Rosalind Krauss offers a complimentary framework to Spielmann's and Schröter's positions that helps understanding aspects of contemporary literary production. Greenberg's interpretation of medium specificity, of which Krauss for many years was an active proponent, ends up as an abstract and generalised idea of the category of the work of art. Krauss sketches a development from minimalism to concept art and then to performance art, claiming that painting and sculpture existed as productive media up until a certain point. After the death of the old "exhausted" or "obsolete" media in the seventies, the "post-medium condition" reigns. Under this condition, new important artworks are being created, but they do not follow what she rather provocatively refers to as the "medium-specific" notion of "obsolete" media nor the kitschy trends of mixing media uncritically. Krauss contends in a series of essays that "these artists do not work with the traditional mediums of painting and sculpture, which they view as exhausted, but are instead forced to do something as counterintuitive as inventing a new medium" (Krauss 2006, 58). 
The two texts discussed below exemplify this dialectical relationship to the medium of literature. The authors have faced the task of creating a book of poems and a novel while being well aware, I believe, that the medium (literature) to which they used to refer has become if not "obsolete" then at least conventionalized and to a high degree commercialized.

\section{Staging Literary Intermediality (The Sea Is a Stage, 2008)}

Havet er en scene [The Sea Is a Stage] is an extraordinarily rich and complex book even when measured against Danish poet Ursula Andkjær Olsen's own standards. ${ }^{3}$ It is divided into sections with titles such as "Auditions to a life without conflicts," "Auditions to the life without costs," "Excerpts from the Sleeping and the Awake" (Part One and Part Two), and "Father of All and King. Of All." The last section, "Appendix to The Sleeping and the Awake," combines earlier textual fragments in the book into new poems. One long poem in turquoise print runs from the front to the back cover and on every page in between. A frontispiece and vignettes by Danish artist Ib Monrad Hansen add another significant layer to the book, as do the figural poems created by the author herself.

The different sections employ a variety of literary styles and forms. The relatively traditional modernist language of the section running at the bottom of the pages contrasts with the banal, everyday language of the section of "auditions." The figural poems of the handwritten parts oppose the systematic, possibly OULIPO-inspired form of the appendix. The stylistic complexity is mirrored in the unusually large number of enunciative positions, or voices, in the book. In the auditions, three voices (mock allegorical figures called Fox [Ræv], Song [Sang] and Wise [Klog]) discuss both banal and serious matters in a Beckettlike absurd dialogue. Another section, "Father of All and King. Of All" stages a discussion of the concept of war (with the right-hand pages consisting of quotes taken from American soldiers' blogs from Iraq and Afghanistan). The book thus creates an intricate web of media mixtures. Drawing upon a useful distinction made by intermediality scholars Irina Rajewsky (2002) and Jörg Helbig (2008, 32), we might say that it stages a number of intramedial (literature quoting or mixing the literary form or content of other literary texts) and intermedial (literature quoting or mixing with non-literary forms and content) relations. ${ }^{4}$

3 Since her debut in 2000, Andkjær Olsen, who was born in 1970, has authored a rich oeuvre of critically acclaimed books of poetry, essays and opera librettos.

4 Irina Rajewsky proposed the term "Intramedialität” for one-medium references in Intermedialität, 2002. For a general discussion of intra- and intermedial relations as the entire field of studies of 
The structure, visual design, and "content" of the book disavow any conventional idea of poetry as subjective voice. ${ }^{5}$ The book transgresses the conventional borders of contemporary print literature by using intramedial and iconicity devices such as handwritten segments, coloured letters and the arrangement of various and discrete verbal tracks placed on different parts of the page. All these aspects may remind the reader of a long tradition of literature including non-verbal, iconic aspects of language going back to figure poems of antiquity as well as modern precursors like the symbolist poetry of Stéphane Mallarmé. Furthermore, the book transgresses the borders between subjects that conventionally are or are not suitable for poetry, such as in the section where Andkjær Olsen combines fragments of American soldiers' blogs to create lyrical texts.

Besides investigating the visual iconic aspects inherent in verbal language and the possibilities of mixing different social discourses, Andkjær Olsen's work stresses the mediated nature of any discourse. The Sea Is a Stage juxtaposes so many different forms of written text that it becomes impossible, and also futile, to decide which discursive level is dominant in the book or to ascertain where the omniscient viewpoint might be.

The "audition section" may exemplify the complexity of Andkjær Olsen's work: Three reviewers, presumably from some kind of TV show, supervise the audition. In a setting reminiscent of the absurdity of Beckett or Ionescoor Kafka's text "Before the Law"-they participate in an absurd dialogue while guarding an entrance never to be entered:

So, do you think anybody will pass?

Asks Song?

No no no no no. Nobody ever came through. Not in my time; it is a totally grotesque show.

Says Fox. Is there any coffee? (Andkjær Olsen 2008, 8) ${ }^{6}$

The characters in this section are gatekeepers of some kind of docu-soap or X-Factor show and the language is mostly banal and torrid, unpoetical in any conventional sense. At the same time, the dialogues include passages of philosophical depth and aspects of social critique and historical references. The titles of the game show ("Audition for a life without costs," and "Audition for

intermediality, see Bruhn 2010.

5 In his reading of Ursula Andkjær Olsen, Peter Stein Larsen also underlines this indirect critique of the idea of the classical modernist enunciative center. See Stein Larsen 2009.

$6 \quad$ "Men tror I så der er nogen der slipper igennem? Spørger Sang?

Nej nej nej nej nej. Der er aldrig nogen der er sluppet igennem. Ikke i min tid; det er et helt grotesk program.

Siger Ræv. Er der noget kaffe?" 
a life without conflicts") suggest a surrounding society transformed into one gigantic reality show. Here, as elsewhere in the book, Andkjær Olsen, when depicting society as a mere popularised image devoid of political meaning (for the protagonists) perhaps refers to Guy Debord's radical social critique in his book The Society of the Spectacle from the sixties. Andkjær Olsen's representation of the non-reality of popular television shows (in contradistinction to the brutal reality of war) may also be seen as a parallel to the critical understanding of popular culture and alienation put forward, for example, by Adorno.

Social critique-even if its theoretical provenience is hard to establish-is an important dimension in The Sea Is a Stage: The text creates a kaleidoscopic version of a number of internally co-referring discourses characterised by the debasing of a conventional poetical discourse through the prominent use of everyday language. This kaleidoscope of stupidity and banality portrays and criticises Danish society and politics in the years of the right-wing administrations of Anders Fogh Rasmussen (2001-2009) and Lars Løkke Rasmussen (20092011) that decisively changed Denmark: from a position as an integrated part of the Scandinavian ideology of the welfare state, Denmark embraced a neoliberal and conservative political position, where it was considered necessary to wage military and cultural wars against threats to "our" civilisation. The clash between escapist game shows and real-time war experiences by living soldiers (and the incorporating of these non-aesthetic aspects in a literary context in the first place) signals that the boundaries between life and art are transgressed in a typical avant-garde fashion.

But, is the "transgressive" avant-garde position still a viable aesthetic and political option? Matias Faldbakken, whose entire production questions the possibility of political transgression, denies this possibility. And, how effective are such devices? From a reader's perspective, the complex, multi-voiced and mixed-media character of the many sections of Andkjær Olsen's book make it difficult to engage psychologically or existentially with the work and to grasp its overall themes. This resistance to direct communication is, however, part of the intended design of the book. Ursula Andkjær Olsen seems well aware of the historicity of her own formal and thematic choices and when applying the "transgressive" avant-garde position she seems to consider it a viable contemporary strategy, politically and aesthetically.

Rosalind Krauss suspects mixed media to be just another expression of numbing capitalist kitsch culture, but I would argue that the intricate and almost overwhelmingly rich form of Andkjær Olsen's book utilises and mirrors the typical layout of much contemporary media and infotainment. The form of her book is not only reminiscent of musical scores (Andkjær Olsen is a musicologist by education): the formal structuring of the book may also be compared to the multiple information tracks running side by side and on top of each other on a 
standard television news channel where the visual interface combines weather forecasts, news headlines, stock exchange levels and conventional interviews on the screen, inviting or rather forcing the viewer to engage in complicated semiotic multi-tasking. Or The Sea Is a Stage may be seen to resemble contemporary computer games. A World of Warcraft gamer, for example, needs to navigate simultaneously between textual messages from co-players and adversaries with constantly changing the advanced settings of the game. Likewise, the soundtracks as well as the many visual styles signify different dimensions of the game to which the gamer must relate. Andkjær Olsen's meta-fictional construction, which juxtaposes acute political questions with absurd game show logic, insists on the productive and even world-saving role of literature in the constant contrast between the "ugly," satiric commentary in her book with epiphanic, and perhaps also desperate, glimpses of exquisite poetic and visual beauty.

Beauty is an effect of the elaborate visual design of her book, and of parts of her text. In a 2005 interview, although she first discusses her attempt to create some kind of relative representation of the complexity and open-endedness of the world, she eventually stresses her search for beauty:

[P]oetry [i]s a possibility of acknowledging the world's-not to mention my own-lack of perfection-even when I accept this non-coherence [of the world and myself], meaning that all this can be used in order to create something beautiful. I can, of course, hear the connotations of marginality [uvæsentlighed] attached to this term; beauty is mere surface and does not change the world, and so on, but I believe in it. (Fangel 2005, my translation $)^{7}$

\section{"Not drama, not development, not an end." (Unfun)}

Attempts to match the complexity and beauty of the world through aesthetically pleasing devices are thus part of the delicate design as well as in the poetic style of certain passages in The Sea Is a Stage. Such attempts are deliberately refuted as an aesthetic possibility in the work of the Norwegian artist Matias Faldbakken. Born in 1973, Faldbakken has published three novels, The Cocka Hola Company (2001), Macht und Rebel (2002), and Unfun (2008), under the pseudonym Abo Rasul. These novels may be compared to the fiction of Michel Houellebecq: Faldbakken's and Houellebecq's works are calculated provocations and clearly foreshadow and encourage future critique in their texts. A major difference, however, is that Faldbakken's work relates to the contemporary art scene (the

7 See http://www.litteratursiden.dk/artikler/jeg-har-slugt-mange-svaner-og-faa-soem-interviewmed-ursula-andkjaer-olsen-og-adda-djoerup (Accessed 16 April 2012) 
novels written under pseudonym are considered adjuncts to his art projects) and is informed by contemporary critical theory, philosophy and art theory, while Houellebecq sees contemporary Western culture in the light of classical philosophical paradigms such as the extreme pessimism (and grim humour) of Arthur Schopenhauer. ${ }^{8}$

Unfun describes a dysfunctional family composed of a hyper-violent father, Slaktus (punning "slaughter" and "slaughterhouse" in Norwegian), his wife Lucy (allegedly from the African "Ik-tribe," characterised by a total inability both to feel or to care about anything) and their two nightmarish twins who have inherited their mother's pathological lack of sensitivity and empathy. Like all protagonists in Faldbakken's fiction, the entire family seems to promote and epitomise that which is not supposed to exist in the Scandinavian welfare state. This is most notably the case with the twins, whom Lucy saves from the corrupting influence of society by not registering them after their birth. They are kept away from all official registers in a kind of Rousseauean primitivism dream and have escaped the socialisation normally provided by attending school and kindergarten. However, they do not become less corrupt and perverted: on the contrary, they spend their time gaming, drinking, smoking, and printing their own money, so the novel seems to argue that the lack of socialisation produces happy but utterly unempathic and cruel subjects.

I read Faldbakken's Unfun as a project with a double focus. On the one hand, the novel stages a political statement, ironic and non-conventional as it may be. On the other, Unfun enters a contemporary paragone discussion (a debate concerning which art ought to be the dominant, see Schnitzler 2007) where literary discourse competes with other media. At first sight, Faldbakken's novels may look like avant-garde or post-avant-garde transgressions of the conventional borders of literary form and style. But as it will become clear below, Faldbakken does not follow any preordained schemes of literary development. Instead, heat least inside the fiction-suggests a non-literary genre as the solution to the problems of literature. His three novels form a veritable catalogue of forms that lie at the edge of the written narrative. The conventional discourse of fiction (dialogue, set description, plot-driven narrative) is constantly inflated with both intermedial and intramedial relations: political speeches, advertising slogans and logos co-exist with fragments of plots for future computer games, descriptions of horror movies and representations of pornographic movies.

Such an intramedial blend of genres and voices (often considered fundamental to the novel form itself) as well as the references to non-literary media, might

8 Until now, the work of Rasul has mostly been met with journalistic criticism and public debate in and outside Norway, and there has been little academic work on Abo Rasul or Matias Faldbakken. To my knowledge, the best analysis of Rasul's literary and philosophical strategy is Skare Malvik 2010. My own reading owes several insights to this article. 
be interpreted as the only justifiable representation of the complexity of contemporary society. A reading, relying on, for instance, M. M. Bakhtin's ideas of heteroglossia and "novelness" in Discourse in the Novel (1981), would focus on the positive, surplus character of numerous perspectives and dimensions that together create a richer version of a given represented reality. But the diversity and multiplicity of discourses in Faldbakken's work would seem to signify the opposite of such an optimistic vision of diversifying plenitude.

On the contrary, the intra- and intermedial diversity in Faldbakken's novels signals a media implosion. Meaning is sucked out of the forms and media used in his work, which results in a general and highly disturbing negativity. Instead of seeing Faldbakken's literary construction as creating a surplus of meaning in a more or less conventional realistic depiction, it is probably more to the point to see it as deeply influenced by Menippean satire. Northrop Frye, in Anatomy of Criticism (1957) considered this genre to be central to the Western imagination from antiquity until our own epoch. The Menippean satire is a philosophical and narrative genre, coloured by both sophism and cynicism (in the philosophical sense of both terms). It mixes points of view in order to create a non-edifying, satiric and materialistic representation of society while debating fundamental questions of truth, justice and human nature. ${ }^{9}$

Consequently, the aesthetics and literary style of Faldbakken owe more to Menippean satire (and conceptual avant-garde art) than to classical standards of "good" writing: rhythm, aural patterns, and cognitively enriching figural language are hard to find. Metaphors, for instance, are used seldom, and when they are, they have a deliberate debasing function in the text, as exemplified in the characterisation of Paris as "a passion filled with foie gras" (Rasul 2008, 58, my translation). Instead, a gruesome, funny, sexually and politically transgressive voice and choice of subjects are the novel's main attractions.

The characters of Faldbakken's novels do not want to participate in the Scandinavian welfare state in Unfun, but several of them have ambitions to make some mark - preferably of a destructive, subversive kind—on society. Faldbakken's protagonists mimic while at the same time also destroying the strategies of what Richard Florida famously named the "creative class" (Florida 2005): artists, people working in advertising, academics, and political sub-groups. In Unfun, the mock-artistic project is aimed at destroying the very idea of narration, in particular film-making, as a symbol of an edifying or even devotional artistic form, and consequently Lucy denounces the generally accepted idea that film is the replacement of the novel's dominating grand narrative in contemporary culture.

9 Christian Dahl discusses Faldbakken/Rasul's novels as examples of Menippean satire in "Scandinavian Misanthropy and Transgression: The Poetics of Matias Faldbakken," unpublished manuscript. See Relihan 1993 and Vignes 1985 for discussions of the history and form of the Menippean satire. 
This is part of Faldbakken's staging of a postmodern paragone. This competition is not between conventional forms such as music, sculpture and painting (or between literature and painting as was the case in the Renaissance). Instead, heavy metal or punk music, and in particular contemporary semi-underground audio-visual media, such as porn and extremely violent movies, rule the cultural universe of the protagonists and compete for their attention. For the protagonists, reading (or writing) literature, such as novels, is an anachronism in a cultural universe where other media have taken over.

Slaktus-the violent husband of the dysfunctional family-first attempts to adapt Joseph Conrad's novel Heart of Darkness into a slasher movie. Instead of a white man travelling into the obscure and dangerous interior of the African continent in order to regularise the colonial trade, as described in Conrad's novel, Slaktus conceptualises an African mass murderer in Paris who uses a road worker's stone cutter to kill his victims. Interpreted from a typical leftwing position, this slasher movie could be understood, his wife Lucy ironises, as "some statement" about "cultural alienation, clash of civilizations or colonial backlash" (Rasul 2008, 72, my translation). Needless to say, the project receives no funding and Faldbakken turns the screw one turn more as the protagonists argue that even pornographic or slasher movies (both characterised by rudimentary narrative plots) are too conventional. Cinema is still too dependent on what Lucy, in an acidly satiric description of the common understanding of narration and storytelling, refers to as the old-fashioned idea of "life as narration," a "recognizable common space that we may kinda identify with and that will glue us together" (Rasul 2008, 74, my translation).

In order to avoid cinematic and literary narrativity, Slaktus's computer game creates "a world existing between the eye and the hand;" that is, without "verbalisation" or reflection. He is, therefore, not interested in a conventional firstperson shooter game and instead sketches a first-person slasher game, a "splatter medium" (Rasul 2008, 74). Narration as pattern, as a meaningful sign of humanity, is actively avoided in the new medium, and Lucy hesitatingly acknowledges that Slaktus is on to something. The "non-form" and extreme open-endedness of the "splatter medium" stand in contrast to cinema and literature: "In fiction it is only the openings [anslag] that are interesting. They are where the ideas are; that is where the potential is. Openings on top of openings on top of openings, potential on top of potential, a flat sequence of openings. Not drama, not development, not an end" (Rasul 2008, 124, my translation). The efficient escapism of gaming lies in its infinite number of openings without endings. Being a non-humanistic, nonedifying, non-structured form that finally facilitates a worthy substitute of real life with its numerous restrictions, the game does not illuminate or enlighten life.

The slasher film's working title "Mbo - Avenging Congo" is changed to the game-title Deathbox and the young computer nerds at the Rapefruit office create 
a graphic design that painstakingly recreates an exact representation of Paris. ${ }^{10}$ A Nigerian male actor is the model for the animation scenes, and the nonfictitious actor Dan Castellaneta, the voice of Homer Simpson in The Simpsons, is brought in to provide the voicing. Faldbakken creates a balance here, as well as elsewhere, between racist jokes and political satire. The brand names, plot of the game and the description of the process of creating the game are both a dystopic representation of contemporary quasi-artistic production and a freewheeling parody. The inclusion of Dan Castellaneta as a non-fictive element (but with fictive features!) disturbs the safe borders between fiction and reality in the text.

Faldbakken's use of literature and the novel to conduct the deadly attack by popular culture might, in fact, be turned critically upon his own project. Unfun is, after all, a kind of novel that follows several of the conventions of novelistic discourse: more or less trustworthy figures, a recognisable setting, a plot driven by identifiable needs (even though the devices of Menippean satire cause it to deviate from conventional novels). Faldbakken's novel provides a double answer to this imagined objection. First, the novel shows that it may be very effective to wage war on the territory of the opponents, to destroy the cultural and artistic street cred of the novel from inside the novel itself. Secondly, the real and radical break with the conventional, edifying novelistic form (first and foremost with narrativity) lies in the formal structure.

The main part of Unfun resembles Faldbakken's two earlier novels. As we have seen, sexually and politically subversive content is combined with an obvious disdain for good taste and literary style. At the same time, a relatively conventional narrative plot forms the structure of the text. Unfun is basically a grotesque parody of a crime plot that creates a (nevertheless) gratifying mixture of humour, suspense, and satire. But in its final chapter, called "Final Girl" in reference to the conventional female protagonist in slasher and horror films (see Clover 1992), new plot logic takes over. ${ }^{11}$

The chapter begins with Lucy being brutally raped by her ex-husband Slaktus. Instead of accepting this as she has done previously, she kills him. Following this murder we are, in a transitional scene, introduced to the virtual reality of Slaktus's computer game. The English script (one of many genres in the book) describes the introductory sequence to the game, ending like this: "We are Mbo now, stone cutter in hand. [...] We are free to act" (Rasul 2008, 241, English in the original). With no clear passage from this virtual reality to the world outside fiction, Lucy takes over as final girl, only in Unfun the final girl has already killed

10 "Deathbox" probably puns Microsofts gaming station Xbox, while "Rapefruit" debases and puns Yoko Ono's avant-garde classic artist's book Grapefruit from 1964. The highly detailed, digital version of Paris is destroyed because of a computer programming mistake later on, initiating one of Slaktus's violent assaults.

11 This has been foreshadowed in a discussion of the "final girl" and of splatterpunk in the first chapter, p. 38-39. 
the violent threat and is herself turning into a killer of partly innocent people.

In this last part of Unfun, Faldbakken creates an unheimlich feeling in the reader: One is not sure which reality s/he is in. We recognise Lucy the narrator, but she also acts strangely abrupt, as if she-like a game-player-is both inside and outside the game. The text points at this when hinting that "the body to one side, the eyes towards the other" (Rasul 2008, 241, my translation). It seems as if a split personality takes the place of the narrator:

What happens now seems to happen after language has shut itself down. I will tell you what is happening without talking, I guess there are only pictures left. Lucy2 has left, Lucy1 disappears too, I feel I am only eye, I am a lens, a kind of gaze, a gaze that moves about, a kind of consciousness with eyes in front. (Rasul 2008, 232, my translation)

Here, the novel is violently overtaken, invaded by another medium: a new game logic takes over, and the rest of the book mimics a game.

The idea of the novel as a "pure" literary form has never been particularly strong, and as I have already mentioned, the history of the novel repeatedly rejects the borders of the genre. However, Faldbakken uses the novel's form as a vehicle for a societal and anarchistic criticism of bourgeois values and as a means to negate the novelistic form itself. What is even more surprising, and what may be seen as a new constellation in the unending renewal of the form of the novel, is the attempt to let the relatively non-narrative medium of gaming take over. This results in a deeply disturbing feeling when Lucy kills a handful of people, including her own two sons, as dispassionately as if she were inside a virtual reality. ${ }^{12}$ And perhaps even more disturbing is the fact that we find no soothing normality “outside" fiction in Faldbakken's version: Being outside the violent and nihilistic fiction means entering the "reality" of Slaktus, a world that is as violent and nihilistic as the computer game he wishes to create.

There seems to be no way out of the fictive universe of Unfun. Thus, Faldbakken has cleverly staged a paragone between the novel and computer games, which triumphs as the violent winner. Faldbakken seems to close all utopian or hopeful exits for his media paragone with this victory. The question, however, is whether the victory of gaming over novelness has a certain promise to it. Not a promise of beauty as in the case of Andkjær Olsen's work, but a promise of emptiness and non-narrativity. Unfun may open up an exhilarating field of "[o]penings on top of openings on top of openings, potential on top of potential, a flat sequence

12 Bret Easton Ellis tested a similar strategy in American Psycho (1991), but Ellis's moralistic criticism of consumer society was supported by narrative signs that imply that the narrator/ protagonist was psychotic and that the entire novel was perhaps nothing but a very lively pornographic phantasy of the male protagonist. 
of openings," in which freedom from meaning and conclusion offers new and potentially fertile political possibilities.

\section{A politics of contemporary "literature"?}

These two literary works are spectacular intermedial and intramedial mixtures, though in different ways that may be worth specifying. In The Sea Is a Stage, the intra- and intermedial mixture is characterised by a "synchronic" co-existence in the text. Andkjær Olsen mixes handwriting, colours and different iconic aspects of language, which results in an unusual visual design. In comparison, Faldbakken's text resembles an “ordinary" novel with no outer signs that reveal its mixed media nature: the novel transforms Conrad's novel into a fictitious game, and is itself partly transformed by the form of gaming.

Ursula Andkjær Olsen mixes discourses, literary genres and the iconic representation of language in order to satirise and criticise aspects of a society of spectacle and the discourses of contemporary Danish politics. The contrast between the audition for a banal TV-show and the very real position of contemporary (Danish) politics toward wars waged outside Denmark and the threatening global ecological disaster creates a sophisticated literary form that transcends conventional literary representation. It may be argued, however, that her complex and multi-level discourse may create the kind of apathy and confusion that she is so eager to prevent.

Matias Faldbakken's novelistic Menippean satires blend aspects of pornographic movies, advertising slogans, and other media with more traditional literary and verbal material. In Unfun it is first of all the gaming in novelistic discourse that marks a real, and unheimlich, effect of mixing media. This "gamification" takes place inside the story (where Conrad's novel is adapted to gaming), but as we have seen, it is also a crucial aspect of the narrative frame (the style of gaming overtaking the form of the novel itself). Both these aspects of the game-influence attempt to avoid any conventional sense of plot and narrativity. This use of gaming as a Trojan horse inside the novel is part of Faldbakken's general attack on literature as a conventional medium and expresses Faldbakken's sketch of an anarchist aesthetic approach to reality.

Following the distinctions made by Jens Schröter, these texts clearly lean toward Gesamtkunstwerk rather than trying to achieve medium-specific purity and they express no concerns whatsoever regarding the problems of mixing of media. On the contrary, they show that by mixing literary genres, or the conventional medium of literature with cinema and gaming, it is possible to gain a critical representation, and thus deeper understanding, of reality. Both texts challenge the genres and media they apparently enter, and like so 
many strategic avant-garde efforts, they question the utility and the political productivity of conventional and culturally accepted forms. By representing and understanding contemporary reality in these particular ways, these texts also offer ways of intervening in contemporary Scandinavian politics and culture. Fusing Spielmann's and Schröter's considerations of intermediality we might argue that by combining (the already mixed) media in the tradition of hybrid art forms and Gesamtkunstwerk, it becomes possible to create works of art that intervene in contemporary politics: mixed media may introduce small grains of sand (cf. Spielmann) into the machinery of contemporary Scandinavian selfunderstanding.

The question is, of course, whether these texts fall under Krauss's criticism of the "international fashion of installation and intermedia work, in which art finds itself complicit with a globalization of the image in the service of capital" (Krauss 1999, 56). She claims that only a tiny portion of contemporary art, and I suggest we include literature in these considerations, grasps the challenge posed by the fact that the ideal of art—as being media specific—has been exhausted. Since she considers the new intermedia ideal to be kitsch, Krauss leaves only limited space for contemporary artistic creation, which must navigate between the Scylla and Charybdis of "obsolete" media and intermedia kitsch. Although it is problematic to translate Krauss's argument from visual art to literature, she does remind us that the mixing of media for the sake of mixing is, in art as in film and literature, not a liberating or enlightening activity per se. And perhaps the most valuable aspect of Krauss's analysis of contemporary art and culture is that she reminds us that the mixing of media is no longer the exception to the rule. Rather, mixing media is the general condition of producing significant, but also consumable, messages in politics, advertising-and art.

Nevertheless, I believe that the two works discussed here do produce a critical effect: they invigorate the media with which they engage. Reaching beyond the conventional form and content of the media of the novel and the book of poems, these aesthetic works seem to take up the challenge of the new (and weakened) position of literature in contemporary Western societies. For these two authors, the co-existence of social critique and beauty (Andkjær Olsen) and the possibility of non-edifying negativity (Faldbakken) are attainable in a mixed-media version of literature. 


\section{Works cited}

Andkjær Olsen, Ursula. 2008. Havet er en scene. [The sea is a stage] København: Gyldendal.

Bakhtin, M. M. 1981. The Dialogical Imagination. Austin: Texas UP.

- 1984. Problems of Dostoevsky's Poetics. Minnesota: Minnesota UP.

Bruhn, Jørgen. 2010. Heteromediality. In Media Borders, Multimodality and Intermediality, ed. Lars Elleström, 225-236. Basingstoke: Palgrave Macmillan.

Clover, Carol J. 1992. Men, Women, and Chainsaws: Gender in the Modern Horror Film. Princeton: Princeton University Press.

Dahl, Christian. Unpublished ms: "Scandinavian Misanthropy and Transgression: The Poetics of Matias Faldbakken."

Debord, Guy. 1970 [1967]. The Society of the Spectacle. Trans. Fredy Perlman and Jon Supak. New York: Black and Red.

Easton Ellis, Bret. 1991. American Psycho. New York: Vintage Books.

Elleström, Lars. 2010. The Modalities of Media. A Model for Understanding Intermedial Relations. In Media Borders, Multimodality and Intermediality, ed. Lars Elleström, 11-49. Basingstoke: Palgrave Macmillan.

—. 2011. Visuell ikonicitet i lyrik: en intermedial och semiotisk undersökning med speciellt fokus på svenskspråkig lyrik från sent 1900-tal. Hedemora: Gidlunds förlag.

Fangel, Gitte. 2005. "Jeg har slugt for mange svaner og for få søm - interview med Ursula Andkjær Olsen og Adda Djørup." http://www.litteratursiden. dk/artikler/jeg-har-slugt-mange-svaner-og-faa-soem-interview-med-ursulaandkjaer-olsen-og-adda-djoerup (Accessed 16 April 2012.)

Florida, Richard. 2005. The Flight of the Creative Class. The New Global Competition for Talent. New York: HarperCollins.

Frye, Northrop. 1957. Anatomy of Criticism. Princeton: Princeton UP.

Helbig, J. 2008. Intermedialität - eine spezifische Form des Medienkontakts oder globaler Oberbegriff? In Media Encounters and Media Theories, ed. Jürgen E. Müller, 79-87. Münster: Nodus.

Koebner, Thomas, ed. 1989. Laokoon und kein Ende: Der Wettstreit der Künste, Litteratur und andere Künste. München: Edition Text und Kritik.

Krauss, Rosalind. 1999. A Voyage on the North Sea. Art in the Age of the PostMedium Condition. London: Thames \& Hudson.

—. 2006. Two Moments from the Post-Medium Condition. October vol. 116: 55-62. Kulish, Nicholas. 2006. "Television you can't put down." The New York Times, September 10. http://www.nytimes.com/2006/09/10/opinion/10sun3.html?_ $r=1$ (Accessed September 1, 2012.) 
Malvik, Anders Skare. 2010. Naivismus, Nihilismus, Negation - zur Ästhetik in Abo Rasuls Unfun. In Figuren des Dazwischen. Naivität in Kunst, Pop- und Populärkultur, eds. Stefan Krankenhagen und Hans-Otto Hügel, 109-133. Wilhelm Fink Verlag.

Mitchell W. J. T. 1994. Picture Theory: Essays on Visual and Verbal Representation. Chicago and London: University of Chicago Press.

-. 2005. There Are No Visual Media. Journal of Visual Culture vol. 4 no. 2: 257-266.

Pethő Ágnes. 2010. Intermediality in Film. A Historiography of Methodologies. Acta Universitatis Sapientiae, Film and Media Studies vol. 2: 39-72.

-. 2011. Cinema and Intermediality. The Passion for the In-between. Newcastle on Tyne: Cambridge Scholars Publishing.

Rajewsky, Irina. 2002. Intermedialität. [Intermediality] Tübingen: A. Francke Verlag.

Rasul, Abo. 2001. The Cocka Hola Company. Skandinavisk misantropi. Oslo: Cappelen.

-. 2002. Macht und Rebel. Skandinavisk misantropi 2. Oslo: Cappelen.

-. 2008. Unfun. Skandinavisk misantropi 3. Oslo: Cappelen.

Relihan, Joel. 1993. Ancient Menippean Satire. Baltimore: Johns Hopkins.

Schnitzler, Andreas. 2007. Der Wettstreit der Künste. Berlin: Reimer Verlag.

Spielmann, Yvonne. 1997. Intermedialität. Das System Peter Greenaway. [Intermediality. The Peter Greenaway system] München: W. Fink.

—. 2010. New and Novelty in Contemporary Media Cultures. Acta Universitatis Sapientiae, Film and Media Studies vol. 3: 7-18.

—. 2010. Hybridkultur. Berlin: Suhrkamp Taschenbuch.

Schröter, Jens. 2010. The Politics of Intermediality - New and Novelty in Contemporary Media Cultures. Acta Universitatis Sapientiae, Film and Media Studies, vol. 2: 107-124.

Stein Larsen, Peter. 2009. Drømme og dialoger. To poetiske traditioner omkring 2000. Odense: Syddansk Universitetsforlag.

Vignes, Jean. 1985. Culture et histoire dans la Satyre Menippee. In Etudes sur la Satyre Mennippée, eds. Frank Lestringant and Daniel Menager, 151-199. Geneva: Droz.

Voigts-Virchow, Eckart. 1991. Metadaptation: Adaptation and Intermediality Cock and Bull. Journal of Adaptation in Film \& Performance, vol. 2, no. 2: 137-152.

Wolf, Werner. 2010. Intermedialität und mediale Dominanz typologisch, funktionsgeschichtlich und akademisch-institutionell betrachtet. In Der Neue Wettstreit der Künste. Legitimation und Dominanz im Zeichen der Intermedialität, eds. Uta Degner and Norbert Christian Wolf, 241-260. Bielefeld: Transcript. 